\title{
Post-crisis Reforms in Banking: Regulators at the Interface between Domestic and International Governance
}

Citation for published version (APA):

Quaglia, L., \& Spendzharova, A. (2017). Post-crisis Reforms in Banking: Regulators at the Interface between Domestic and International Governance. Regulation \& Governance, 11(4), 422-437. https://doi.org/10.1111/rego.12157

Document status and date:

Published: 01/12/2017

DOI:

10.1111/rego.12157

Document Version:

Publisher's PDF, also known as Version of record

Document license:

Taverne

Please check the document version of this publication:

- A submitted manuscript is the version of the article upon submission and before peer-review. There can be important differences between the submitted version and the official published version of record.

People interested in the research are advised to contact the author for the final version of the publication, or visit the DOI to the publisher's website.

- The final author version and the galley proof are versions of the publication after peer review.

- The final published version features the final layout of the paper including the volume, issue and page numbers.

Link to publication

\footnotetext{
General rights rights.

- You may freely distribute the URL identifying the publication in the public portal. please follow below link for the End User Agreement:

www.umlib.nl/taverne-license

Take down policy

If you believe that this document breaches copyright please contact us at:

repository@maastrichtuniversity.nl

providing details and we will investigate your claim.
}

Copyright and moral rights for the publications made accessible in the public portal are retained by the authors and/or other copyright owners and it is a condition of accessing publications that users recognise and abide by the legal requirements associated with these

- Users may download and print one copy of any publication from the public portal for the purpose of private study or research.

- You may not further distribute the material or use it for any profit-making activity or commercial gain

If the publication is distributed under the terms of Article $25 \mathrm{fa}$ of the Dutch Copyright Act, indicated by the "Taverne" license above, 


\title{
Post-crisis reforms in banking: Regulators at the interface between domestic and international governance
}

\author{
Lucia Quaglia (iD* \\ Department of Politics, University of York, York, UK \\ Aneta Spendzharova \\ Political Science Department, Maastricht University, Maastricht, Netherlands
}

\begin{abstract}
Post-crisis international standards have been agreed on in certain areas of banking regulation, namely capital, liquidity, and resolution, but not others, namely bank structure - why? We articulate a two-step analytical framework that links the domestic and international levels of governance. In particular, we focus on the role of domestic regulators at the interface between the two levels. At the domestic level, regulators evaluate externalities and adjustment costs before engaging in cooperation at the international level. This analysis explains why regulators in the United States and the European Union act as pacesetters, foot-draggers, or fencesitters in international standard setting; that is to say, why they promote, resist, or are neutral toward international financial standards. At the international level, we explain the outcome of international standard setting by considering the interaction of pacesetters and foot-draggers.
\end{abstract}

Keywords: banking regulation, governance of finance, international standard, regulator, post-crisis reform.

\section{Introduction}

The international financial crisis was first and foremost a banking crisis, thus many post-crisis regulatory reforms focused on banks. These reforms can be grouped under three main headings: (i) prudential capital and liquidity requirements for banks, (ii) bank resolution regimes, and (iii) rules on bank structure. ${ }^{1}$ In the wake of the crisis, the Group of Twenty (G20) leaders pledged:

We are committed to take action at the national and international levels to raise standards together so that our national authorities implement global standards consistently in a way that ensures a level playing field and avoids fragmentation of markets, protectionism, and regulatory arbitrage. (Group of 20 [G20] 2009)

However, international standards were agreed in the first two areas of banking regulation, namely capital/liquidity and resolution, but not in the third area, bank structure. This variation is puzzling.

In 2010, substantially revised international prudential standards were issued by the Basel Committee on Banking Supervision (BCBS 2010), Basel III: A global regulatory framework for more resilient banks and banking systems, setting capital and liquidity requirements for internationally active banks (Young 2012; Lall 2015; Goldbach 2015a,b). Endorsed by the G20, Basel III was more than 200 pages long and the implementation of the Accord was monitored by a BCBS working group specifically set up for that purpose. In 2011, the Financial Stability Board (FSB 2011a) agreed on new international standards on resolution, the Key Attributes of Effective Resolution Regimes. The Key Attributes were about 100 pages long, were endorsed by the G20, and their implementation was monitored by the International Monetary Fund (IMF) and the World Bank as part of their Financial Sector Assessment Program. By contrast, no international standards were agreed upon concerning bank structures. The FSB, with the collaboration of the Organisation for Economic Co-operation and Development (OECD) and the IMF, conducted a stocktaking exercise of the domestic

Correspondence: Lucia Quaglia, Department of Politics, University of York, Heslington, York YO10 5DD, UK. Email: lucia. quaglia@unibo.it

Accepted for publication 17 April 2017.

(C) 2017 John Wiley \& Sons Australia, Ltd 
reforms adopted by the main jurisdictions (FSB 2014a). Indeed, several jurisdictions adopted new rules about the structural separation of deposit-taking from trading activities, but international standards were not set. The central puzzle in this article is to explain why, after the crisis, international standards were agreed upon in certain key areas of banking regulation but not in others. Answering this question will shed light on broader patterns in global regulation: how can we explain the extent of regulatory change in the aftermath of crises and why are global rules set (or not)?

In order to address these questions, we focus on the "great financial powers," that is, jurisdictions with large domestic financial markets and regulatory capacity (Drezner 2007). On the one hand, in contrast to other policy areas, such as biotechnology or food products, concentrated interests and a rather limited number of global systemically important financial institutions that seek to shape the scope and the content of international regulations characterize the financial sector. On the other hand, as Drezner has pointed out, "multinational corporations may have some leverage vis-à-vis small states, but governments with significant markets can easily coerce them into compliance with their own rules and regulations" (2007, p. 35). In our view, this remains an important feature of the post-crisis international regulatory environment in banking. Scholars have highlighted the importance of domestic interests and institutions in shaping the extent to which regulators are willing to engage in international cooperation in the governance of financial securities and insurance (Bach \& Newman 2014; Fioretos 2010). Furthermore, the interaction between first-mover regulators who introduce new rules early on and regulators who lag behind has been observed in other policy areas, such as forestry, clothing, IT-electronics, and chemicals regulation (Fransen \& Conzelmann 2015).

This article introduces a novel analytical framework to more systematically unpack the causal mechanisms that link regulators' actions at the international level to their concerns at the domestic level. In particular, we focus on the role of domestic regulators at the intersection between the two levels. At the domestic level, we consider the negative externalities concerning financial stability and domestic adjustment costs in order to explain why regulators in the United States (US) and the European Union (EU) act as pacesetters, foot-draggers, or fence-sitters ${ }^{2}$ in international standard setting; that is, why they promote, resist, or are neutral toward international financial standards. At the international level, we explain the outcome of international standard setting by considering the interaction of pacesetters and foot-draggers.

We make two main theoretical contributions to the literature. First, our framework systematically links the domestic and international levels, drawing attention to the role of domestic regulators at the interface between the two levels. In particular, regulators seek to find a balance between externalities and adjustment costs. On the one hand, they need to negotiate an acceptable international deal with their foreign counterparts. On the other hand, regulators are constrained by the fact that standards have to be acceptable to key domestic constituencies, such as banks and elected officials. Second, we suggest that international standards emerge if regulators in the great financial powers sponsor the new rules. However, this is a necessary but not a sufficient condition if there are powerful foot-draggers. When regulators in major jurisdictions do not sponsor international standards but there is consensus on the issues at stake, jurisdictions are likely to opt for similar domestic rules.

The article begins by reviewing the literature on international regulatory harmonization. It then outlines the analytical framework and the research design, which are subsequently applied to international standard setting (or the lack thereof) on capital/liquidity, resolution, and bank structures. Empirically, we map and explain the core post-crisis reforms of international banking regulation, as well as "negative cases," in which new standards were not set.

\section{State of the art}

The body of scholarly work on international regulatory harmonization, in particular standard setting, is vast and includes policy areas that range from manufacturing, trade and finance to food safety and environmental protection. In this section, we demonstrate that explanations based on historical institutionalism, transnational governance, and the power of the financial industry cannot systematically account for the outcomes of post-crisis global banking regulation. We then review explanations of international regulatory cooperation that connect the domestic to the international arena, which we seek to refine by unpacking the causal mechanisms that link regulators' actions at the international level to their considerations at the domestic level.

A historical institutionalist explanation ${ }^{3}$ would argue that large jurisdictions that first regulate a given sector or activity will seek to "upload" (Quaglia 2014a,b) their domestic rules as international standards by exploiting first-mover advantages (Posner 2010). However, the recent dynamics of international standard setting in banking show that not all 
jurisdictions that are first-movers domestically are also pacesetters internationally and vice versa. In the case of banking regulation, the US and the United Kingdom (UK) adopted domestic rules on resolution and bank structure in the aftermath of the international financial crisis (James 2015; Ryan \& Ziegler 2015; Germain 2016; Spendzharova 2016). Subsequently, whereas on resolution these jurisdictions promoted international standards in line with their newly issued national legislation, they did not do so on bank structure. On capital and liquidity, all jurisdictions waited for international standards to be set by the Basel III accord before revising their national legislation. However, the US and the UK were actively engaged in the international standard-setting process on capital and liquidity, despite the fact that they had not set domestic rules on the matter.

Scholars of transnational governance point out how the activities of "transnational policy communities of experts" (Tsingou 2008, p. 21, 2015; Djelic \& Quack 2010; Tsingou 2015), "technical elite networks" (Lall 2015, p. 125), and "transnational business governance schemes" (Porter 2014, p. 110) promote international coordination. For example, Kapstein (1992) defined the BCBS as an embryonic "epistemic community." Other works focus on domestic regulatory changes resulting from "transnational feedbacks" (Newman \& Posner 2016, p. 123) that derive from international standards. Attention is also drawn to policy interdependence, whereby "decisions made in one polity or market have consequences in another" (Farrell \& Newman 2014a, p. 332, 2014b; Djelic \& Quack 2010).

Yet in the wake of the crisis, the transnational policy community in finance came "under stress" (Tsingou 2010) because there was "much less consensus on optimal regulatory models" (Helleiner \& Pagliari 2011, p. 189) and financial regulation was less insulated than in the past from politics and politicians (Pagliari 2013). For example, in accounting standards, regulators were not able to agree on how and when to apply core principles such as fair value accounting (Mügge \& Stellinga 2015, p. 52). Moreover, it is more difficult to reach a consensus on the strengthening of regulation post-crisis than on making it more market-friendly, as it was pre-crisis. Furthermore, transnational standard-setting fora suffer from limited direct democratic accountability to voters (see Black 2008; Mügge 2011), which is particularly problematic when international standards have potential fiscal implications domestically, as in the case of post-crisis banking rules.

Another explanation for the presence (or, more likely, the absence) of international standards could be the power of the industry directly affected by regulation (see Mattli \& Woods 2009). This is especially relevant in finance, where large financial institutions have considerable structural and lobbying power (Underhill \& Zhang 2008; Baker 2010; Lall 2012; Grossman \& Woll 2013; Culpepper \& Reinke 2014; Woll 2014). Thus, regulators may be "captured" by the financial industry, which might be able to prevent domestic and international regulation on certain matters, such as derivatives prior to the crisis (Pagliari 2013; Knaack 2015), or to promote regulation that is industry-friendly, as in the case of Basel II (Lall 2012; Goldbach 2015a,b).

Other scholars have qualified the power of the financial industry by pointing out the different competing preferences of the financial industry (Young 2012; Pagliari \& Young 2014), as well as the mobilization of non-financial companies (Young \& Pagliari 2017) and consumer groups (Kastner 2014) that seek to affect international standard setting as well as domestic rulemaking. After the crisis, at least in the short to medium term, the financial industry received a less sympathetic hearing from regulators (Helleiner \& Pagliari 2011; Young 2013). Significant domestic regulatory reforms concerning bank structures were enacted in the US and the UK, despite strong opposition from the financial industry (James 2015; Ryan \& Ziegler 2015). Once domestic rules were agreed, one would have expected the financial industry to push for the "externalization" of the new (and from the industry's perspective), costly domestic rules to other jurisdictions by means of international standards.

Finally, our argument builds on explanations that link the international and domestic levels, considering states at the forefront of setting international financial standards (Fioretos 2010; Simmons 2001; Singer 2004, 2007; Drezner 2007; Rixen 2013; Thiemann 2014; Goldbach 2015a,b). These explanations have focused on the main standard-setting jurisdictions by examining their externalities (Simmons 2001), adjustment costs (Drezner 2007), the attempt to balance financial stability and competitiveness (Singer 2004, 2007), the quest for a level playing field (Rixen 2013; Goldbach 2015a,b), and concerns about regulatory competition, often resulting in a race to the bottom (Thiemann 2014).

\section{Analytical framework and research design}

The explanandum of this research is the presence or absence of post-crisis international standards in three key areas of banking regulation, namely capital/liquidity, resolution, and bank structure. Hence, the focus is on the outcome of 
international standard setting, which also requires an investigation of the process of standard setting. Like Drezner (2007), Singer (2004, 2007), Rixen (2013), and Newman and Posner (2016), we focus on two "great financial powers," the US and the EU, which have large domestic markets and domestic regulatory capacity. This choice was made on the grounds that international standard setting in finance is currently based on "bipolarity" - the "Euro-American regulatory condominium" (Posner 2009, p. 665). ${ }^{4}$ In order to better understand the position of the EU, which is a multi-level jurisdiction and often lacks cohesiveness in international financial fora, we "zoom in" on the three member states with the largest banking sectors - the UK, France, and Germany (like Rixen 2013; Goldbach 2015a). These three member states often have different preferences concerning financial regulation and are important players within the EU as well as in international fora. Indeed, prior to the establishment of the Banking Union in 2015, the European Commission and the European Central Bank only had observer status in the BCBS and the FSB, whereas France, Germany, and the UK were full members with voting power.

We apply a two-step analytical framework that links the domestic and the international level (see also Putnam 1988). In particular, we focus on the role of domestic regulators at the interface between the two levels. These regulators are civil servants (meaning non-elected officials), working for the banking supervisory authorities. Domestic regulators are "new diplomats" (Slaughter 2004, p. 14) because they have a prominent role in negotiating international standards, given the level of required technical knowledge. The expertise of non-majoritarian regulators is particularly sought after in "technocratic" issue areas with low political salience (Levi-Faur 2005).

Regulators are "reluctant diplomats" (Singer 2007, p. ix) because they would prefer to stay out of the political limelight and avoid controversy. Their mandate is primarily domestic and so is their indirect accountability (see Black 2008; Zaring 2013). Therefore, domestic regulators' main concern is not to look for optimal policy solutions that maximize international welfare (see Mattli \& Woods 2009). Rather, they are mindful of the implications of international standards for the domestic banking system they oversee. Consequently, the process of setting international standards does not simply revolve around establishing consensus on the technical details; it also involves striking a balance between the domestic political economy concerns of various jurisdictions.

A substantial body of literature points out that financial regulators are keen to maintain their autonomy and avoid the excessive interference of politicians in financial regulation (Macey 2003; Singer 2004, 2007; Verdier 2009). In order to ensure their autonomy, regulators need to adequately address the main issues concerning financial regulation at the domestic level. While some issues that cannot be solved through unilateral action provide a powerful incentive to pursue international regulatory cooperation, others bring forward strong domestic concerns and reluctance toward international solutions. Our analytical framework focuses on two factors that capture the need to reconcile incentives that work in opposite directions: externalities and adjustment costs. As we will show, externalities "push" regulators to seek solutions at the international level, while adjustment costs "pull" regulators in the opposite direction. Consequently, regulators need to balance the two factors when engaging in international cooperation. Overall, in our framework, the interplay of externalities and adjustment costs explains why regulators decide to promote, resist, or remain neutral toward international standards.

To begin with, there are the negative externalities for financial stability deriving from the absence of international standards or from inadequate standards that, therefore, need to be changed. Indeed, domestic regulators often have to deal with problems that threaten domestic financial stability but are externally generated, or result from cross-border activities (see Simmons 2001). In certain cases, externalities cannot be dealt with through domestic banking regulation and unilateral action is insufficient, or not cost-effective, to insulate a jurisdiction from "imported" financial instability. In the banking sector, negative externalities are particularly high for jurisdictions that are "home" of and "host" to a large number of cross-border banks, especially global systemically important banks (G-SIBs). Hence, the level of cross-border banking and the number of G-SIBs are a good way to operationalize potential externalities, even though, depending on the specific issue at stake, there might be ways to avoid these externalities through unilateral action domestically. For the sake of simplicity, we distinguish between high and low negative externalities.

The second factor affecting the preferences of regulators is the expected domestic adjustment costs related to the adoption of international standards (see Drezner 2007). These costs can be direct, that is, the costs for the national banking sector (and banks therein) to switch over to these rules, and indirect, that is, the effects of these rules on credit provision to the real economy. Indirect adjustment costs are significant in jurisdictions in which banks (and not capital markets) provide most of the funding to the non-financial sector. Adjustment costs are a primary concern for the financial industry, which will then lobby domestic regulators on the matter. These costs can be gauged by looking at 
position papers issued by banks and banking associations, as well as the responses to stakeholder consultations prior to the adoption of new rules and independent regulatory impact assessment reports. For the sake of simplicity, we again distinguish between high and low adjustment costs.

Negative externalities and adjustment costs vary across jurisdictions, which leads to the different engagement of domestic regulators in international standard setting. Domestic regulators will act as pacesetters if their jurisdiction suffers from high negative externalities and low domestic adjustment costs. They will resist international financial standards, acting as foot-draggers if the jurisdiction suffers from low negative externalities and high domestic adjustment costs. They will be fence-sitters, neither opposing nor promoting international standards, if the jurisdiction is subject to low negative externalities and low domestic adjustment costs. They will be partial foot-draggers if the jurisdiction suffers from high negative externalities and high domestic adjustment costs.

In step one, which focuses on the domestic level, we unpack the key considerations that shape domestic regulators' preferences on international standards (see Table 1). Several qualifications are in order. First, the importance that domestic regulators attach to the objective of financial stability will partly depend on the domestic political salience of the issue (Pagliari 2013). Post-crisis, elected officials have become more involved in regulatory reforms because of the potential fiscal implications of bank failures (Helleiner \& Pagliari 2011). Elected officials do not directly participate in international standard setting; however, they can still signal their concerns to regulators. If jurisdictions bore significant fiscal costs resulting from bank bailouts during the crisis and regulators anticipate substantial future fiscal exposure, they will seek to implement stricter banking rules. At the same time, if regulators can safeguard financial stability and limit potential fiscal exposure through domestic regulation, there is no need to promote international standards. Regulators are willing to negotiate with their foreign counterparts at the international level only if there are negative externalities that cannot be addressed through domestic rules (see Singer 2004, 2007).

Second, domestic adjustment costs might be unequally distributed within jurisdictions. For example, a bank in a given jurisdiction might be well capitalized and ready to meet new capital standards, whereas the rest of the national banking sector is not. At the same time, adjustment costs tend to be correlated within national banking systems. These are often referred to as "systems" (rather than simply "sectors"), in which individual banks are closely related to each other (Hardie \& Howarth 2013). Furthermore, even if the adjustment costs are different for different parts of the banking industry, regulators are likely to consider the aggregate adjustment costs for the national banking system they oversee and its link to the real economy.

At the international level, the analysis focuses on the regulators of the jurisdictions with large banking sectors (Table 2). Our explanation is sensitive to the interactive dynamics at the international level: international standard setting is about how jurisdictions make rules together, taking into account their domestic political economy. Therefore, the outcome of international standard setting will depend on the interaction between pacesetters and foot-draggers. Fence-sitters are not crucial to the outcome. International standards will emerge if there are pacesetters. If there are no foot-draggers, international standard setting will be uncontroversial, as will the standards that are set. If there are partial foot-draggers, international standard setting will involve time-consuming negotiations and the outcome will be a compromise between the different positions. No international standards will emerge if there are no pacesetters. If there are no foot-draggers, jurisdictions are likely to adopt similar domestic rules (e.g. through policy diffusion), even if there are no formal international standards. However, if there are foot-draggers, national regulatory divergence is likely to prevail.

Table 1 Domestic preferences on international standards

Externalities

\begin{tabular}{llll}
\cline { 2 - 3 } & \multicolumn{1}{c}{ High } & \multicolumn{1}{c}{ Low } \\
\hline Adjustment costs & High & $\begin{array}{l}\text { Partial foot-draggers (continental } \\
\text { EU member states on Basel III) } \\
\text { Low }\end{array}$ & $\begin{array}{l}\text { Foot-draggers (continental EU member states } \\
\text { on bank structure) }\end{array}$ \\
& and Basel) & $\begin{array}{l}\text { Fence-sitters (US and UK on bank structure; } \\
\text { continental EU member states on resolution) }\end{array}$ \\
\hline
\end{tabular}

EU, European Union; UK, United Kingdom; US, United States. 
Table 2 The outcome of international standard setting

\begin{tabular}{llll}
\hline & & \multicolumn{2}{c}{ Foot-draggers } \\
\cline { 2 - 4 } & & \multicolumn{1}{c}{ Yes } & No \\
\hline Pacesetters & Yes & $\begin{array}{l}\text { Contested international standards } \\
\text { (Basel III) }\end{array}$ & International standards (resolution) \\
& No & $\begin{array}{l}\text { No international standards, different } \\
\text { rules across jurisdictions (bank structure) }\end{array}$ & $\begin{array}{l}\text { No international standards, similar rules across } \\
\text { jurisdictions (macroprudential supervision) }\end{array}$ \\
\hline
\end{tabular}

${ }^{\dagger}$ Note that in this case there were partial foot-draggers.

It is important to distinguish between partial foot-draggers and foot-draggers tout court because international standards can be set if the regulators of the great financial powers are partial foot-draggers, but not if they are footdraggers tout court. As illustrated in Table 1, the former are subject to high externalities and high adjustment costs, whereas the latter are faced with low externalities and high adjustment costs. If regulators in either the EU or the US are partial foot-draggers because of high negative externalities, they will agree to international standards, but will seek to modify their content in order to reduce domestic adjustment costs. If regulators in either the EU or the US are footdraggers tout court, they are unlikely to agree to international standards. Therefore, in our framework the extent of negative externalities is the crucial threshold, or incentive, for action, explaining why foot-draggers may be willing to agree to international standards. The following sections assess the explanatory leverage of this analytical framework in three empirical cases of post-crisis regulatory reforms in banking.

While our empirical analysis focuses on the great financial powers, it is also important to briefly discuss the incentives of regulators in other jurisdictions and implications for the outcome of international standard setting. Small and medium-sized jurisdictions are also influenced by the incentives for international standard setting, such as externalities and adjustment costs. For example, Switzerland was exposed to major negative externalities because of the size and openness of its banking sector. Consequently, Swiss regulators joined US and UK regulators in promoting the Basel III accord (Financial Times, 4 October 2010). When there are major negative externalities, regulators in small or medium-sized jurisdictions will seek alliances to support international standard setting. By contrast, regulators in small and medium sized jurisdictions that have low externalities and high adjustment costs are likely to (unsuccessfully) resist international standards. For example, this was the case of emerging economies regarding the standards that were adopted under the aegis of US and EU regulators after the Asian financial crisis (Drezner 2007; Walter 2008). At any rate, regulators in jurisdictions that are not great financial powers are unlikely, on their own, to be able to promote or resist the setting of international standards. In certain cases, domestic regulators might be keen to impose stricter regulation domestically and might be willing to agree to international standards as a way to lock in stricter rules, as suggested by the logic of the "external constraint" in a two-level game (Putnam 1988).

\section{Post-crisis international capital and liquidity standards}

Capital and liquidity requirements are the centerpiece of prudential banking regulation: they enable banks to withstand financial shortfalls, improving financial stability. The BCBS set capital requirements for banks for the first time in 1989 with the Basel I accord, which was superseded by the Basel II accord in 2005. The international financial crisis revealed that the existing capital rules were inadequate and liquidity rules were absent (Brunnermeier et al. 2009; Financial Services Authority [FSA] 2009; Group of Thirty 2009).

\subsection{Domestic level: Externalities and adjustment costs}

With respect to capital and liquidity rules, jurisdictions with a very internationalized banking sector - meaning those that are home to, but especially those that host large cross-border banks - are very exposed to negative externalities concerning financial stability. The level of foreign bank penetration is particularly relevant because the financial stability of host jurisdictions can be threatened by undercapitalized foreign banks operating in their territory. It is true that foreign banks operating as subsidiaries (not branches) are subject to capital rules set by the hosts (see Epstein 2014). 
However, if the foreign banking group as a whole is undercapitalized and/or has insufficient liquidity, this has negative repercussions for its subsidiaries. Indeed, during the international financial crisis, the US Federal Reserve had to provide a substantial amount of emergency funding to the subsidiaries and branches of foreign undercapitalized and liquiditystarved banks operating in the US, notably Barclays and Deutsche Bank. Foreign subsidiaries and branches, in turn, transferred part of that funding to their parent companies in Europe (Harding et al. 2010). Jurisdictions with low levels of foreign bank penetration are less exposed to these negative externalities, which are therefore unevenly distributed across jurisdictions.

In the UK, about 40 percent of the banking sector is foreign owned, the majority of which is owned by banks headquartered outside of the EU. The levels of foreign bank penetration in the US and EU are similar - slightly below 30 percent - but with important differences. First, most of the EU cross-border banking is intra-EU (i.e. to and from other EU countries $)^{5}$ and, on average, foreign penetration by non-EU headquartered banks is below 10 percent in the EU as a whole. Second, in "core" EU countries, such as France and Germany, foreign (EU and non-EU) bank penetration is the lowest in the EU and does not exceed 10 percent (Schoenmaker 2013). Consequently, the externalities deriving from financial instability imported through the operation of foreign banks were lower in France and Germany than in the UK and the US.

In the US and the UK, the adjustment costs deriving from new international capital and liquidity standards were low. The massive government-led recapitalization of ailing US and UK banks during the crisis left them relatively well capitalized afterwards. For example, one senior British bank representative indicated that British banks would have preferred lower capital requirements (see also Barclays 2010; HSBC 2010), but also that "they could live with the new levels set in Basel III." ${ }^{6}$ US banks reiterated a similar view. ${ }^{7}$ US banks already complied domestically with the leverage ratio, which had been in place in the US since the 1990s. In the UK, banks were subject to liquidity rules introduced by the British FSA (2009) in the midst of the crisis. Furthermore, capital markets in the US provided the bulk of funding to the real economy. Similarly, the banking sector, especially wholesale investment banking in the City of London, did not provide substantial funding to the national economy in the UK. Hence, the impact of new international capital and liquidity requirements on economic growth in the US and the UK was expected to be lower than in continental Europe (Howarth \& Quaglia 2015).

In France and Germany, the adjustment costs to the new international capital and liquidity standards were high for banks and the real economy. ${ }^{8}$ German banks were massively undercapitalized and French banks had severe liquidity shortages. The association representing all German banks asked for a grandfather clause on Basel III capital rules of "at least 30 years" (Zentraler Kreditausschuss 2010, p. 3). The French Banking Federation considered the BCBS proposal to include a leverage ratio as "completely unacceptable" (Fédération Bancaire Française 2010, p. 6). The former governor of the Banque de France argued that the riskiness of the activities of "traditional" European universal banks was lower than that of (largely Anglo-Saxon) investment banks and that this feature would not be captured by a crude leverage ratio (de Larosiere 2010). In Germany and France, banks provided most of the credit to the real economy, thus stricter capital and liquidity rules would have been detrimental to economic growth. A 2011 IMF study suggested a particularly significant impact of the proposed Basel III rules upon bank lending in Germany and a comparatively small drop in the UK, with France somewhere in between (Cosimano \& Hakura 2011).

\subsection{International level: Presence of pacesetters and foot-draggers}

Given the combination of high negative externalities and low domestic adjustment costs, US and UK regulators acted as pacesetters for new international capital and liquidity standards. A member of the Board of the Federal Reserve, Daniel Tarullo, advocated a revision of international capital standards in order to promote international financial stability, arguing that "weaknesses in one group of internationally active firms could quickly be transmitted globally" (Tarullo 2011). ${ }^{9}$ As for the specific content of post-crisis international prudential standards, an influential review published by the British FSA (2009) in the wake of the crisis called for an increase in "the quality and quantity of capital... significantly above existing Basel rules," a "maximum gross leverage ratio," and "liquidity regulation and supervision." These positions were also shared by US regulators (see Ryan \& Ziegler 2015) who, together with UK regulators, were very active in the BCBS working groups dealing with various aspects of Basel III. The British FSA co-chaired the BCBS Working Group on the Definition of Capital, the Bank of England and Federal Reserve co-chaired the BCBS Working 
Group on Liquidity, and the Federal Reserve and the Securities and Exchange Commission co-chaired the BCBS Working Group on the Trading Book.

France and Germany had limited (but not negligible) externalities and high adjustment costs. Because of the presence of non-negligible externalities, continental regulators were partial foot-draggers in international standard setting. They sought to tone down the proposals put forward by the US and the UK concerning the content of Basel III and the timetable proposed for its implementation, but still supported an international agreement. French and German regulators argued for a less strict definition of capital (to include silent participations and hybrids). They resisted high capital requirements, opposed the leverage ratio and liquidity rules, and asked for a longer transition period (The Economist, 21 January 2010; Financial Times, 4 October 2010). At a crucial meeting shortly before signing the new agreement, the German regulators threatened to veto the agreement unless a longer transition period was granted. ${ }^{10}$

The outcome of the international standard-setting process was the Basel III accord agreed upon in December 2010 (BCBS 2010). The accord was a compromise between the positions of pacesetters and partial foot-draggers. It tightened up the definition of what counts as capital, but left some national flexibility; it increased the capital requirements, but by less than what had been proposed by US and UK regulators; it set up a leverage ratio; and it outlined liquidity management rules. The (contested) Basel III rules were to be phased in with a long transition period from 2013 until 2019. US and UK regulators were dissatisfied with Basel III and shortly after signing it, they began promoting new international standards on loss-absorbing capacity, which are on the borderline between capital standards and resolution rules. ${ }^{11}$ The EU, under the impulse of continental countries, implemented Basel III with modifications and was found to be "materially non-compliant" with several provisions of the accord (BCBS 2014).

\section{Post-crisis international standards on bank resolution}

The international financial crisis, which was indeed triggered by the disorderly resolution of a large cross-border investment bank, Lehman Brothers, revealed that resolution regimes were unfit for purpose (Brunnermeier et al. 2009; FSA 2009; Group of Thirty 2009). The resolution of cross-border banks was particularly problematic because the cooperation between national resolution authorities proved to be difficult during the crisis. The crisis also revealed that certain banks were "too big to fail" and had to be rescued using taxpayers' money.

\subsection{Domestic level: Externalities and adjustment costs}

The international financial crisis drew attention to the high negative externalities related to the resolution of cross-border banks, whereas in the past national regulators regarded resolution mainly as a domestic issue that could be managed at the national level without the need for international standards (Goodhart 2011). Jurisdictions with a very internationalized banking sector are exposed to very high negative externalities concerning resolution. The ability of countries that are home to large cross-border banking groups - first and foremost, G-SIBs - to resolve those banks without jeopardizing financial stability is curtailed if hosts conduct uncoordinated actions using different resolution instruments and strategies. At the same time, the financial stability of host jurisdictions is at risk if the home jurisdiction resolves a cross-border bank without considering the effects on the hosts. In the UK, the day after Lehman Brothers filed for bankruptcy in the US, $£ 3$ billion in cash was moved from the UK subsidiary to its parent company in the US and the London subsidiary had no funding left to pay its staff or its bills (Elliott \& Treanor 2013).

The UK and the US are home, respectively, to four and eight out of 30 G-SIBs. The three largest UK-headquartered banks hold the majority of their assets internationally, mostly outside the EU. The US and especially the UK also host many G-SIBs, as indicated by the relatively high level of foreign bank penetration discussed in the previous section. Moreover, the UK and US banking systems are highly interconnected. As the chairman of the Federal Deposit Insurance Corporation (FDIC), Gruenberg (2013) noted: "nearly seventy percent of the on and off balance sheet assets of our major institutions are held in the UK." In December 2012, the Bank of England and the FDIC released a joint paper on "Resolving Globally Active, Systemically Important, Financial Institutions." This bilateral document is significant because it explicitly stated that it implemented some aspects of new international standards on resolution issued by the FSB in 2011, which are further discussed. 
Germany and France are home to one and four G-SIBs, respectively (FSB 2014b), but only two of the largest French banks hold more than 25 percent of their assets outside France, mainly within the EU (Howarth \& Quaglia 2015). Although the EU as a whole is home to 10 G-SIBs, these banks (including the French and German G-SIBs) predominantly engage in EU cross-border banking, especially within the Euro area, and thus have a limited global reach. Indeed, during the international financial crisis, the largest and most contested case of resolution of an EU cross-border bank was Fortis, which involved primarily Belgium and the Netherlands (Kudrna 2012). The EU as a whole, with the exception of the UK, was less exposed to the negative externalities related to the resolution of truly global G-SIBs. Thus, after the financial crisis, the EU focused on setting up regional rules on resolution, especially when the sovereign debt crisis in the Euro area intensified (Quaglia 2017). ${ }^{12}$

Unlike capital and liquidity rules, resolution rules do not have major direct domestic adjustment costs. It is true that if the regulators are not satisfied about the resolvability of a bank, they can require some restructuring of its business operations in order to make it easier to resolve. However, these are within the remit of bank structural reforms, discussed in the following section, rather than rules on resolution as such. Alternatively, the regulators can require higher capital, as envisaged by the prudential rules discussed in the previous section. The only direct adjustment costs related to the new resolution rules are very limited, concerning the preparation of living wills for banks. ${ }^{13}$ Unlike capital and liquidity requirements, resolution rules do not have direct implications for the real economy. The absence of significant direct adjustment costs for the financial industry is confirmed by the broadly consensual responses to the FSB's consultation on resolution rules (British Bankers Association 2011; Fédération Bancaire Française 2011; Global Financial Markets Association et al. 2011).

\subsection{International level: Presence of pacesetters and absence of foot-draggers}

Given the high externalities and low adjustment costs, US and UK regulators acted as pacesetters internationally. ${ }^{14}$ Tarullo, a member of the Board of Governors of the US Federal Reserve (2013), argued "very large financial firms ... have extensive cross-border activities, and thus implicate the legal systems of other countries." Therefore, he called for international standards to promote the harmonization of resolution regimes across jurisdictions (see also Gruenberg 2012). The Deputy Governor of the Bank of England, Paul Tucker (2010) highlighted the complexity of "resolving cross-border banking groups," arguing that "policymakers need to face up to, and decide whether or not to fix, the really big issues about how insolvency and resolution laws are applied to internationally active financial companies." As for the content of new international standards on resolution, the main proposals put forward by US and UK regulators were as follows: the instrument of bail-in, converting debt into equities as a means of recapitalizing a failed bank; the strategy of the single point of entry, which gives the home resolution authorities the lead in resolution; and the use of "living wills" that specify the recovery and resolution of ailing banks (James 2015; Ryan \& Ziegler 2015; Germain 2016). These proposals were eventually included in the international standards issued by the FSB (2011a).

The chairing of key international financial regulatory committees and fora by US and UK regulators was instrumental to their pacesetting efforts. From 2007 onwards, the FDIC co-chaired the Cross-Border Bank Resolution Group of the BCBS, which produced a key report in 2009. The Federal Reserve Bank of New York chaired the FSB's Crisis Management Group. The Deputy Governor of the Bank of England, Tucker, chaired the FSB Resolution Steering Group that drafted the Key Attributes and co-chaired the Steering Group established jointly by the Committee on Payments and Settlements Systems and the International Organization of Securities Commissions. The head of the British FSA (before it was disbanded) chaired the FSB Standing Committee on Supervisory and Regulatory Cooperation.

Limited externalities and low adjustment costs meant that the continental EU regulators mainly acted as fencesitters in the process of international standard setting. Unlike in the case of capital adequacy standards, they were not foot-draggers and broadly supported the US and UK proposals (Quaglia 2017). The activity of pacesetters and the absence of foot-draggers resulted in new international standards on resolution: the Key Attributes of Effective Resolution Regimes for Financial Institutions (2011) issued by the FSB, which build on work also undertaken by the BCBS and the IMF. The negotiations of the Key Attributes were quite consensual: jurisdictions agreed on the need for post-crisis standards and the content of those standards. ${ }^{15}$ The Key Attributes were officially endorsed by the G20 (2011) at a summit in Cannes in November 2011 "as the international standard for resolution regime." They 
were also designated as "key international financial standards (2017)" by the FSB. However, despite the issuing of these standards, when implemented in actual cases, the resolution of ailing financial institutions remains a controversial issue.

\section{Absence of post-crisis international standards on bank structure}

The international financial crisis revealed that many banks were "too big/complex to fail," but also that deposit-taking institutions had moved away from "traditional" banking and engaged in "risky" financial activities, which made those banks more likely to need resolution. Several jurisdictions enacted bank structural reforms domestically, such as ringfencing in the UK or restrictions on proprietary trading in the US. However, unlike in prudential regulation and resolution, no common post-crisis international standards were issued on bank structures.

\subsection{Domestic level: Externalities and adjustment costs}

Rules on bank structures were intended to address the problem of "too big to fail," particularly relevant for G-SIBs. As noted by the FSB, the most far-reaching domestic bank structural reforms were adopted in jurisdictions that were "home to global systemically important banks, as well as host to substantial operations of global systemically important banks" (FSB 2014b, p. 1). The Volcker Rule, part of the Dodd-Frank Act (2010), prohibits US and foreign banking entities in the US from engaging in proprietary trading, meaning short-term, speculative risk-taking that is separate from activities performed for a client. Furthermore, these entities should not invest in, sponsor, or have certain relationships with hedge funds or private equity funds (Federal Deposit Insurance Corporation 2015). Introduced in the UK, ring-fencing is another approach to simplify banking structures and reduce risk exposure in the deposit-taking banking entity. The UK reforms require a clear separation of deposit-taking and investment activities in different legal entities (James 2015; Hardie \& Macartney 2016; Spendzharova 2016).

Unlike in the preceding two cases, the externalities deriving from the lack of international standards on bank structures could be addressed through domestic regulation. Large UK-based banks, such as HSBC, Standard Chartered, Barclays, and the Royal Bank of Scotland (RBS), accepted the UK domestic reforms, but opposed further reforms at the European or international level. Standard Chartered argued that additional "structural reform is unnecessary to improve financial stability and address systemic risk" (2013, p. 1). In the US, the Volcker rule applied to foreign banks operating in the US ${ }^{16}$ as well as to US banks operating abroad. Similarly, in the UK, ring-fencing also applied to foreign banks operating in UK territory. This highlights the importance of externalities as a crucial "push" to seek an agreement at the international level. In the absence of substantial negative externalities, jurisdictions do not have sufficiently strong incentives to sponsor international rules.

The anticipated adjustment costs were the highest for the so-called "universal banks" in continental Europe. While a recent BIS assessment does not provide concrete cost estimates, it highlights that universal banks will need to raise greater amounts of local funding in their subsidiaries and reduce their trading activities as a result of restrictions on market-making operations (Gambacorta \& van Rixtel 2013, p. 10). An IMF assessment of ongoing banking structural reforms in the US, the UK, and the EU also stressed the negative impact on market liquidity, higher borrowing costs, and lower diversification benefits for universal banks when compared to other banking business models (Viñals et al. 2013, p. 19).

Consequently, French and German regulators introduced limited domestic reforms driven by strategic considerations of the high adjustment costs for universal banks (Hardie \& Macartney 2016, p. 6). As stated in a joint position of the French and German regulators, "[i]t is of vital importance to secure that no activities have to be separated that serve the financing needs of the economy" (Joint German and French Response 2013 p. 1). According to French and German regulators, their domestic capital markets would be hurt significantly by the mandatory separation of a broad range of capital market activities, including market making, which is a natural complement to securities underwriting (Joint German and French Response 2013, p. 2). The Governor of the Banque de France, Christian Noyer, described the common bank structure reforms proposed at the European level as "irresponsible and contrary to the interests of the European economy" (O'donnell 2014). This position was aligned with the preferences of large French banks such as Crédit Agricole, which warned that additional EU reforms "would run the risk of ... driving costs upwards, raising uncertainty among clients and investors, and hampering efforts towards economic growth" (Crédit Agricole 2013, p. 4). Overall, in contrast to the stricter ring-fencing approach taken in 
the UK, the German and French domestic reforms did not require a forceful change in the ownership of the trading subsidiaries (Ryan \& Ziegler 2015; Hardie \& Macartney 2016).

Historically, universal banks have played a central role in the French and German economies; a similar argument applies to Italy, Spain, Sweden, Denmark, and the Netherlands. This reflects a historical legacy in EU member states of building "national champions" in banking that would be viable in a competitive global financial sector (Hardie \& Howarth 2013). Universal banks conduct both investment banking and retail banking activities. Requiring strict separation of deposit-taking and investment activities in legally separate entities would undermine their very business model. Therefore, French and German regulators favored less strict domestic reforms that would preserve the universal banking model and, consequently, the functioning of their domestic capital markets and the competitiveness of universal banks (Hardie \& Macartney 2016, p. 5).

\subsection{International level: Absence of pacesetters and presence of foot-draggers}

Given the relatively low externalities, which could be addressed domestically, and the significant adjustment costs, the US and the UK did not act as pacesetters at the international level, but instead focused on the domestic level. A systematic analysis of official statements by key US and UK regulators, such as the Chairs of the FDIC in the US, Sheila Bair and Martin Gruenberg, the FDIC Vice Chair, Thomas Hoenig, as well as the Chair of the UK Independent Commission on Banking, Lord John Vickers, reveals that they did not push for common international standards on banking structures. Instead, as we show, when it comes to reforming bank structures, US and UK regulators focused on mitigating the problem of banks that were "too big to fail" through domestic regulation.

In the US, the purpose of the rules on bank structure was to address the moral hazard problem by limiting the possibility that banks would receive implicit subsidies from the US government for risky trading activities (Bair 2009; Hoenig 2013). Similarly, the main objective of ring-fencing in the UK was to safeguard domestic financial stability and improve competition in the domestic banking market. As the Chancellor, George Osborne (2013), emphasized, "[w]e want our banks to support our national economy, not be supported by our national economy." Furthermore, both the House of Commons and House of Lords exerted pressure on the UK government to enact stringent reforms and reduce the likelihood of taxpayer-funded bank bail-outs (James 2015, p. 8). The domestic focus of banking structural reforms is visible in the final recommendations of the UK Independent Commission on Banking (ICB). It called for supplementary regulatory action at the national level, because "ring-fencing the core deposit-taking entity from investment banking activities conducted by the parent company would help insulate retail banking from external financial shocks" (Independent Commission on Banking [ICB] 2011, p. 10).

At the same time, as we saw in the beginning of this section, given the low externalities and high adjustment cost, German and French regulators were foot-draggers. The absence of powerful pacesetters and the presence of tenacious foot-draggers resulted in the absence of international standards on bank structure. The FSB has been active in disseminating information and mediating in case of regulatory inconsistencies, but it has not pursued a common international standard. Instead, the FSB has focused on monitoring the reforms in different jurisdictions and signaling concerns about overlapping requirements or inconsistencies (Ryan \& Ziegler 2015, p. 10). As noted by the FSB (2014b), "[j]urisdictions implementing structural banking reforms emphasize that the reforms support the international reform agenda and promote global financial stability." Yet even when such problems were identified, the FSB left it to domestic regulators to solve the issues and "agree to criteria for mutual recognition of one another's requirements" (FSB 2014b, p. 17).

Another area of banking regulation where we observe a lack of international standards is macroprudential regulation. In that case, there were neither domestic regulators promoting international standards nor foot-draggers. Several jurisdictions, including the US and the EU, adopted similar new post-crisis macroprudential regulation domestically (see Baker 2013; Lombardi \& Moschella 2017). One could argue that a common international standard would be set because domestic regulators across jurisdictions shared the same policy paradigm or had similar regulatory ideas and vice versa. Yet the new macroprudential paradigm, which was sponsored by the Bank for International Settlement (Baker 2013), gained ground in several jurisdictions after the crisis, but international standards in this area were not set, despite this ideational convergence.

That said, ideational convergence can facilitate international standard setting, and at the same time international standards can facilitate ideational convergence across jurisdictions. In the case of the post-crisis reform of resolution 
regimes, the concepts of "bail-in" and "loss-absorbing capacity," sponsored mainly by the US and the UK, gained widespread acceptance and were included in international standards, which in turn affected the reform of domestic resolution regimes. For example, the bail-in rule was included in the EU's Bank Recovery and Resolution Directive (2014). By contrast, diverging ideas about the risk posed by banks that are "too big to fail" (see Goldstein \& Véron 2011) reinforced the focus of regulators to pursue different domestic banking structural reforms.

\section{Conclusion}

This research began with an empirical puzzle: why were post-crisis international standards agreed to in certain areas of banking regulation, namely capital/liquidity and resolution, but not in others, namely bank structure? In order to answer this question, we focused on the great financial powers, namely the US, the EU and its member states with large banking sectors (the UK, France, and Germany). We first explained why regulators in these jurisdictions acted as pacesetters, foot-draggers, or fence-sitters in international standard setting. Regulators assess externalities and adjustment costs at the domestic level before deciding whether to engage in cooperation at the international level. We then explained the outcome of the standard-setting process by looking at the interactions of pacesetters and foot-draggers at the international level.

The analytical framework developed in the article explains variation in international post-crisis reforms in banking and can be extended to other financial services and areas of public regulation. There are several proposals for further research. First, because China is emerging as a new great financial power, future research should also consider this player at the international level. China is not included in our analysis because during the period we examine it was predominantly engaged in "downloading" international standards rather than seeking to shape them (People's Bank of China 2015, pp. 137-141). ${ }^{17}$ Second, this research has not examined the domestic implementation of post-crisis international standards, which would have required a different (top down) research design, but is an interesting avenue for further research. It might well be the case that jurisdictions partly dissatisfied with international standards subsequently "adjust" those standards to the domestic context, as in the case of the EU and the Capital Requirements Directive IV (2013), which implemented Basel III in the EU, albeit with several modifications.

\section{Acknowledgments}

We wish to thank the editors and the reviewers for their helpful comments. This article was written while Lucia Quaglia was a research fellow first at the BIGSSS (University of Bremen) and the Hanse-Wissenschaftskolleg (HWK) and then at the Scuola Normale Superiore (SNS), Florence.

\section{Notes}

1 The regulation of shadow banking does not focus on banks as such (see Rixen 2013), hence, it is not examined in this article. It is touched on, however, in the discussion of prudential regulation (risk-weighted capital requirements) and bank structure (separation of certain trading activities). For a discussion of patterns of post-crisis regulatory changes in finance, see Moschella \& Tsingou 2013.

2 We borrow this terminology from Börzel (2002).

3 See the special issue of the Review of International Political Economy 17(4) 2010; Bach \& Newman 2007; Posner 2009, 2010; and Büthe \& Mattli 2011.

4 On the "externalization" of the EU's regulatory power, see Bradford 2015.

5 With the notable exception of EU-based G-SIBs, such as Deutsche Bank, BNP Paribas, HSBC, and Barclays.

6 Interview, London, March 2012.

7 Interview, Washington, May 2012.

8 Interviews, Paris, July, May 2011; Frankfurt, July 2011.

9 Interviews, Washington, August 2011.

10 Interview, Frankfurt, April 2012.

11 This point was made very forcefully under the Chatham House Rule in February 2015 during an event in Brussels attended by the author.

12 Interviews, Brussels, September 2013; March 2016.

13 Interviews, Brussels, March 2012; Washington, August 2011; London, March 2012.

14 Interviews, Washington, August 2011 and May 2012; London, May 2015; Brussels, September 2013.

15 Interviews, Washington, August 2011 and May 2012; London, May 2015; Brussels, September 2013. 
16 Furthermore, the initial version of the Volcker Rule had a strong extra-territorial reach whereby some of its provisions would apply not only to the parts of the foreign financial institutions operating in the US, but also to the foreign banking group as a whole.

17 Interview, Beijing, July 2012.

\section{References}

Bach D, Newman AL (2007) The European Regulatory State and Global Public Policy: Micro-institutions, Macro-influence. Journal of European Public Policy 14, 827-846.

Bach D, Newman AL (2014) Domestic Drivers of Transgovernmental Regulatory Cooperation. Regulation \& Governance 8, $395-417$.

Bair S (2009) "Deposit Insurance Corporation on regulating and resolving institutions considered 'too Big To Fail,"” statement before the U.S. Senate, Committee on Banking, Housing, and Urban Affairs, Washington, DC, May 6, [Last accessed 9 May 2017.] Available from: https://www.fdic.gov/news/news/speeches/archives/2009/spmay0609.html.

Baker A (2010) Restraining Regulatory Capture? Anglo-America, Crisis Politics and Trajectories of Change in Global Financial Governance. International Affairs 86, 647-663.

Baker A (2013) The New Political Economy of the Macroprudential Ideational Shift. New Political Economy 18, 112-139.

Barclays (2010) Response to the Consultation on Basel III. 16 April, London. [Last accessed 6 June 2016.] Available from: http://www. bis.org/publ/bcbs165/barclayscapital.pdf

BCBS (Basel Committee on Banking Supervision) (2010) Report and Recommendations of the Cross-border Bank Resolution Group: Final Paper. March. Bank for International Settlements, Basel.

BCBS (2014) Regulatory Consistency Assessment Programme (RCAP): Assessment of Basel III Regulations - European Union. December. Bank for International Settlements, Basel.

Black J (2008) Constructing and Contesting Legitimacy and Accountability in Polycentric Regulatory Regimes. Regulation \& Governance 2, 137-164.

Börzel TA (2002) Member State Responses to Europeanization. Journal of Common Market Studies 40, $193-214$.

Bradford A (2015) Exporting Standards: The Externalization of the EU's Regulatory Power via Markets. International Review of Law and Economics 42, 158-173.

British Bankers Association (2011) Response to the FSB's Consultation on key Attributes for Resolution Regimes. September. [Last accessed 10 June 2016.] Available from: http://www.fsb.org/wp-content/uploads/c_110909k.pdf

Brunnermeier M, Crockett A, Goodhart C, Persaud AD, Shin HS (2009) The Fundamental Principles of Financial Regulation. Geneva Reports on the World Economy, 11. International Center for Monetary and Banking Studies, Geneva, Centre for Economic Policy Research, London.

Büthe T, Mattli W (2011) The New Global Rulers: The Privatization of Regulation in the World Economy. Princeton University Press, Princeton, NJ.

Cosimano TF, Hakura DS (2011) Bank Behavior in Response to Basel III: A Cross-Country Analysis. IMF Working Paper No. WP/11/ 119. International Monetary Fund, Washington, DC.

Crédit Agricole (2013) Response to the Commission's Consultation. July, Brussels. [Last accessed 9 May 2017.] Available from: http://ec.europa.eu/finance/consultations/2013/banking-structural-reform/index_en.htm

Culpepper PD, Reinke R (2014) Structural Power and Bank Bailouts in the United Kingdom and the United States. Politics \& Society 42, 427-454.

Djelic M-L, Quack S (eds) (2010) Transnational Communities: Shaping Global Economic Governance. CUP, Cambridge, UK.

Drezner DW (2007) All Politics is Global: Explaining International Regulatory Regimes. Princeton University Press, Princeton, NJ.

de Larosiere J (2010) Basel Rules Risk Punishing the Wrong Banks, Financial Times, London. [Last accessed 26 October 2010.]

Elliott L, Treanor J (2013) Lehman Brothers collapse, five years on: 'We had almost no control'. The Guardian 13 September 2013, London.

Epstein RA (2014) Assets or Liabilities? The Politics of Bank Ownership. Review of International Political Economy 21, $765-789$.

Farrell H, Newman AL (eds) (2010) Making Global Markets: Historical Institutionalism in International Political Economy. Review of International Political Economy 17, 609-638.

Farrell H, Newman AL (2014a) Domestic Institutions Beyond the Nation State: Charting the New Interdependence Approach. World Politics 66, 331-363.

Farrell H, Newman A (2014b) The New Politics of Interdependence: Cross-national Layering in Trans-atlantic Regulatory Disputes. Comparative Political Studies 48, 497-526.

FDIC (Federal Deposit Insurance Corporation) (2015) Selected Sections of the Dodd-Frank Wall Street Reform and Consumer Protection Act. FDIC, Washington, DC.

Fédération Bancaire Française (2010) Response to the Consultation on Basel III. 16 April, Basel. [Last accessed 22 February 2017.] Available from: https://www.bis.org/publ/bcbs165/frenchbankingfe.pdf 
Fédération Bancaire Française (2011) Response to the FSB’s Consultation on Key Attributes for Resolution Regimes. 2 September. FBF Paris. [Last accessed 22 February 2017.] Available from: http://www.fsb.org/wp-content/uploads/c_110909aa.pdf

Financial Times Reporters (2010) Reforming the Global Financial System, Financial Times, 4 October 2010, London.

Financial Services Authority (FSA) (2009) The Turner Review: A Regulatory Response to the Global Banking Crisis. March. FSA, London.

Financial Stability Board (FSB) (2011a) Key Attributes of Effective Resolution Regimes for Financial Institutions. November. FSB, Basel.

Financial Stability Board (FSB) (2011b) List of Global Systemically Important Banks. November. FSB, Basel.

Financial Stability Board (FSB) (2014a) 2014 Update of List of Global Systemically Important Banks (G-SIBs). 6 November. FSB, Basel.

Financial Stability Board (FSB) (2014b) Structural Banking Reforms. Cross-Border Consistencies and Global Financial Stability Implications. Report to G20 Leaders for the November 2014 Summit, 27 October. FSB, Basel.

Fioretos O (2010) Capitalist Diversity and the International Regulation of Hedge Funds. Review of International Political Economy 17, 696-723.

Fransen L, Conzelmann T (2015) Fragmented or Cohesive Transnational Private Regulation of Sustainability Standards? A Comparative Study. Regulation \& Governance 9, 259-275.

G20 (Group of Twenty) (2009) G20 Leaders Statement: The Pittsburgh Summit. 24-25 September 2009, Pittsburgh, PA.

G20 (2011) 'Communiqué G20 Leaders Summit-Cannes -3-4 November 2011'. [Last accesed 10 May 2017.] Available from URL: https://www.oecd.org/g20/summits/cannes/Cannes Leaders Communiqué 4 November 2011.pdf.

G30 (Group of Thirty) (2009) Financial Reform: A Framework for Financial Stability. G30, Washington, DC.

Gambacorta L, van Rixtel A (2013) Structural Bank Regulation Initiatives: Approaches and Implications. BIS Working Papers No. 412, April. Bank for International Settlements, Basel.

Germain R (2016) Locating Authority: Resolution Regimes, SIFIs and the Enduring Significance of Financial Great Powers. Journal of Banking Regulation 17, 34-45.

Global Financial Markets Association, The Clearing House Association, American Bankers Association, The Financial Services Roundtable, Institute of International Bankers, Institute of International Finance (2011) Response to the FSB's Consultation on key Attributes for Resolution Regimes. September, Basel. [Last accessed 9 May 2017.] Available from: http://www.fsb.org/ wp-content/uploads/c_110909cc.pdf

Goldbach R (2015a) Global Governance and Regulatory Failure: The Political Economy of Banking. Palgrave, Basingstoke.

Goldbach R (2015b) Asymmetric Influence in Global Banking Regulation, Transnational Harmonization, the Competition State, and the Roots of Regulatory Failure. Review of International Political Economy 22, 1087-1127.

Goodhart C (2011) The Basel Committee on Banking Supervision: A History of the Early Years 1974-1997. CUP, Cambridge, UK.

Goldstein M, Véron N (2011) Too big to fail: the transatlantic debate. Bruegel Working Paper No. 2011/03. [Last accessed 9 May 2017.] Available from: http://bruegel.org/2011/02/too-big-to-fail-the-transatlantic-debate/.

Grossman E, Woll C (2013) Saving the Banks: The Political Economy of Bailouts. Comparative Political Studies 47, 574-600.

Gruenberg MJ (2012)International Harmonization of Wall Street Reform: Orderly Liquidation, Derivatives, and the Volcker Rule before the Committee on Banking Housing and Urban Affairs, United States Senate. 22 March. FDIC, Washington, DC.

Gruenberg MJ (2013) Remarks by Martin J. Gruenberg, Chairman, FDIC to the Volcker Alliance Program. 13 October. FDIC, Washington, DC.

Hardie I, Howarth D (eds) (2013) Market-based Banking and the International Financial Crisis. OUP, Oxford.

Hardie I, Macartney H (2016) EU Ring-Fencing and the Defence of Too-Big-to-Fail Banks. West European Politics 39, $503-525$.

Harding R, Braithwaite T, Guerrera F (2010) European Banks Took Big Slice of Fed Aid. Financial Times 2 December 2010, London.

Helleiner E, Pagliari S (2011) The End of an Era in International Financial Regulation? A Postcrisis Research Agenda. International Organization 65, 169-200.

Hoenig TM (2013) Banking Safety Net Makes Wall Street Dangerous. American Banker, 17 Jan.

Howarth D, Quaglia L (2015) The Comparative Political Economy of Basel III in Europe. Edinburgh School of Law Research Paper No. 2015/19 and Europa Working Paper No 2015/03.

HSBC (2010) Response to the Consultation on Basel III. 16 April. HSBC, London. [Last accessed 9 May 2017.] Available from: http://www.bis.org/publ/bcbs165/hsbccapital.pdf

ICB (Independent Commission on Banking) (2011) Final Report Recommendations. September. ICB, London.

James S (2015) The UK in the Multilevel Process of Financial Market Regulation: Global Pace-Setter or National Outlier? In: Mayntz R (ed) Multilevel Governance of Financial Market Reform, pp. 121-137. Max Planck Institute, Cologne.

Joint German and French Response (2013) Joint Response to the Consultation on Reforming the Structure of the EU Banking Sector. July, Berlin. [Last accessed 9 May 2017.] Available from: http://ec.europa.eu/finance/consultations/2013/banking-structuralreform/docs/contributions/public-authorities/germany-and-france-joint-response_en.pdf 
Kapstein EB (1992) Between Power and Purpose: Central Bankers and the Politics of Regulatory Convergence. International Organization 46, 265-287.

Kastner L (2014) “Much Ado about Nothing?” Transnational Civil Society, Consumer Protection and Financial Regulatory Reform. Review of International Political Economy 21, 1313-1345.

Key standards for sound financial systems (2017) [Last accessed 10 May 2017.] Available from URL: http://www.fsb.org/what-we-do/ about-the-compendium-of-standards/key_standards/.

Knaack P (2015) Innovation and Deadlock in Global Financial Governance: Transatlantic Coordination Failure in OTC Derivatives Regulation. Review of International Political Economy 22, 1217-1248.

Kudrna Z (2012) Cross-border Resolution of Failed Banks in the European Union after the Crisis: Business as Usual. Journal of Common Market Studies 50, 283-299.

Lall R (2012) From Failure to Failure: The Politics of International Banking Regulation. Review of International Political Economy 19, 609-638.

Lall R (2015) Timing as a Source of Regulatory Influence: A Technical Elite Network Analysis of Global Finance. Regulation \& Governance 9, 125-143.

Levi-Faur D (2005) The Global Diffusion of Regulatory Capitalism. Annals of the American Academy of Political and Social Science 598, 12-32.

Lombardi D, Moschella M (2017) The symbolic politics of delegation: macroprudential policy and independent regulatory authorities. New Political Economy 22, 92-108.

Macey JR (2003) Regulatory Globalization as a Response to Regulatory Competition. Faculty Scholarship Series. Paper 1418. Yale Law School, New Haven, CT.

Mattli W, Woods N (eds) (2009) The Politics of Global Regulation. Princeton University Press, Princeton, NJ.

Moschella M, Tsingou E (2013) Regulating Finance after the Crisis: Unveiling the Different Dynamics of the Regulatory Process. Regulation \& Governance 7, 407-416.

Mügge D (2011) Limits of Legitimacy and the Primacy of Politics in Financial Governance. Review of International Political Economy $18,52-74$.

Mügge D, Stellinga B (2015) The Unstable Core of Global Finance: Contingent Valuation and Governance of International Accounting Standards. Regulation \& Governance 9, 47-62.

Newman A, Posner E (2016) Transnational Feedback, Soft law, and Preferences in Global Financial Regulation. Review of International Political Economy 23, 123-152.

O’ donnell J (2014) Europe's bid to reform mega-banks hits resistance in France. Reuters 29 January 2014.

Osborne G (2013) Speech by the Chancellor of the Exchequer, RT Hon George Osborne MP, at Mansion House 2013. 19 June, London.

Pagliari S (2013) Public Salience and International Financial Regulation. Explaining the International Regulation of OTC Derivatives, Rating Agencies, and Hedge Funds. PhD dissertation, University of Waterloo, Ontario.

Pagliari S, Young KL (2014) Leveraged Interests: Financial Industry Power and the Role of Private Sector Coalitions. Review of International Political Economy 21, 575-610.

Peoples Bank of China (2015) Financial Stability Report. Beijing. [Last accessed 7 May 2017.] Available from: http://www.pbc.gov.cn/ english/130736/2946072/2015090616281480816.pdf.

Porter T (2014) Technical Systems and the Architecture of Transnational Business Governance Interactions. Regulation and Governance 8, 110-125.

Posner E (2009) Making Rules for Global Finance: Transatlantic Regulatory Cooperation at the Turn of the Millennium. International Organization 63, 665-699.

Posner E (2010) Sequence as Explanation: The International Politics of Accounting Standards. Review of International Political Economy 17, 639-664.

Putnam RD (1988) Diplomacy and Domestic Politics: The Logic of Two-Level Games. International Organization 42, 427-460.

Quaglia L (2014a) The European Union and Global Financial Regulation. OUP, Oxford.

Quaglia L (2014b) The European Union, the USA and International Standard Setting by Regulatory Fora in Finance. New Political Economy 19, 427-444.

Quaglia L (2017) 'The political economy of post-crisis international standards for resolving financial institution'. New Political Economy, http://www.tandfonline.com/doi/full/10.1080/13563467.2017.1270927.

Rixen T (2013) Why Reregulation after the Crisis is Feeble: Shadow Banking, Offshore Financial Centers, and Jurisdictional Competition. Regulation \& Governance 7, 435-459.

Ryan PJ, Ziegler NJ (2015) Patchwork Pacesetter: The United States in the Multi-Level Process of Financial Market Regulation. In: Mayntz R (ed) Multilevel Governance of Financial Market Reform, pp. 65-96. Max Planck Institute, Cologne.

Schoenmaker D (2013) Governance of International Banking: The Financial Trilemma. OUP, Oxford. 
Simmons BA (2001) The International Politics of Harmonization: The Case of Capital Market Regulation. International Organization 55, 589-620.

Singer DA (2004) Capital Rules: The Domestic Politics of International Regulatory Harmonization. International Organization 58, 531-565.

Singer DA (2007) Regulating Capital: Setting Standards for the International Financial System. Cornell University Press, Ithaca, NY. Slaughter A-M (2004) A New World Order. Princeton University Press, Princeton, NJ.

Spendzharova AB (2016) Regulatory Cascading: Limitations of Policy Design in European Banking Structural Reforms. Policy and Society 35, 227-237.

Standard Chartered (2013) Response to the Commission's Consultation. July, Brussels. [Last accessed 9 May 2017.] Available from: http://ec.europa.eu/finance/consultations/2013/banking-structural-reform/docs/contributions/registered-organisations/standardchartered-group_en.pdf.

Tarullo DK (2011) Capital and Liquidity Standards Testimony before the Committee on Financial Services, US House of Representatives. 16 June. Washington DC.

Tarullo DK (2013) Toward Building a More Effective Resolution Regime: Progress and Challenges. 18 October. Washington, DC.

Thiemann M (2014) In the Shadow of Basel: How Competitive Politics Bred the Crisis. Review of International Political Economy 21, 1203-1239.

Tsingou E (2008) Transnational Private Governance and the Basel Process: Banking Regulation, Private Interests and Basel II. In: Graz J-C, Nölke A (eds) Transnational Private Governance and Its Limits, pp. 58-68. Routledge, London.

Tsingou E (2010) Regulatory Reactions to the Global Credit Crisis: Analyzing a Policy Community under Stress. In: Helleiner, E. Pagliari S. \& Zimmerman H. (eds) Global Finance in Crisis: The Politics of International Regulatory Change, pp. 21-36. Routledge, London.

Tsingou E (2015) Club Governance and the Making of Global Financial Rules. Review of International Political Economy 22, $225-256$.

Tucker P (2010) Remarks by Paul Tucker, Deputy Governor, Financial Stability, Bank of England at the European Commission's Conference on Crisis Management, Brussels, Belgium. 19 March.

Underhill GRD, Zhang X (2008) Setting the Rules: Private Power, Political Underpinnings, and Legitimacy in Global Monetary and Financial Governance. International Affairs 84, 535-554.

Verdier P-H (2009) Transnational Regulatory Networks and their Limits. The Yale Journal of International Law 34, $113-172$.

Viñals J, Pazarbasioglu C, Surti J, Narain A, Erbenova M, Chow J (2013) Creating a Safer Financial System: Will the Volcker, Vickers, and Liikanen Structural Measures Help?, [Last accessed 22 February 2017.] Available from: https://www.imf.org/external/pubs/ft/ $\operatorname{sdn} / 2013 /$ sdn1304.pdf.

Walter A (2008) Governing Finance: East Asia's Adoption of International Standards. Cornell University Press, Ithaca, NY.

Woll C (2014) The Power of Inaction: Bank Bailouts in Comparison. Cornell University Press, Ithaca, NY.

Young KL (2012) Transnational Regulatory Capture? An Empirical Examination of the Transnational Lobbying of the Basel Committee on Banking Supervision. Review of International Political Economy 19, 663-688.

Young K (2013) Financial Industry Groups' Adaptation to the Post-crisis Regulatory Environment: Changing Approaches to the Policy Cycle. Regulation \& Governance 7, 460-480.

Young KL, Pagliari S (2017) Capital United? Business Unity in Regulatory Politics and the Special Place of Finance. Regulation \& Governance 11, 3-23.

Zaring D (2013) Sovereignty Mismatch and the New Administrative Law. Washington University Law Review 91, 59-112.

Zentraler Kreditausschuss (2010) Strengthening the Resilience of the Banking Sector. Position Paper on the Consultative Document of the Basel Committee, April, Berlin.

\section{Laws cited}

Directive 2013/36/EU of the European Parliament and of the Council of 26 June 2013 on access to the activity of credit institutions and the prudential supervision of credit institutions and investment firms, amending Directive 2002/87/EC and repealing Directives 2006/48/EC and 2006/49/EC Text with EEA relevance.

Directive 2014/59/EU of the European Parliament and of the Council of 15 May 2014 establishing a framework for the recovery and resolution of credit institutions and investment firms.

Dodd-Frank Wall Street Reform and Consumer Protection Act of 2010, Pub. L. No. 111-203, 12 U.S.C. 5301 (2010). 